\title{
Instruments Construct Model for Evaluation of Character Education in Madrasah Tsanawiyah (Islamic Junior Schools Under Mora)
}

\author{
Umum Budi Karyanto*1, Zamroni ${ }^{2}$, Badrun Kartowagiran ${ }^{3}$ \\ 1,2,3 Universitas Negeri Yogyakarta, Indonesia
}

\begin{abstract}
This study aims to develop a construct of an instrument of character education evaluation model in MTs in the area of former Pekalongan residency. It is a development research using Borg and Gall model with the number of samples involving 64 students for a limited test and 292 students for a large-scale test, as well as 8 teachers. The sampling technique used disproportionate stratified random sampling. To find out the number of samples, the Slovin formula was used. Meanwhile, data collection was done by distributing questionnaires and observations. The data were analysed using a quantitative and qualitative descriptive analysis technique. To improve the validity and reliability of the instruments, a CFA was done through the Lisrel 8.5 program. The instrument construct so that a fit model is obtained, seen from the following indicators: (a) Chi-Square, the value obtained = 789,9 ; (b) GFI, the value obtained $=0.83$; (c) RMSEA, the value obtained $=0,071$. The judgment for face validity and content validity in the model is good (0.73), while construct validation with CFA shows that all variables appear to have a factor load value of $(\lambda)>0.30$. The estimated reliability of the model instrument using the Cronbach Alpha formula has met the minimum standard index, which is above 0.7. The empirical character education evaluation model has been declared feasible in the implementation test on the users
\end{abstract}

Keywords

character education, madrasa, instrument construct model, evaluation

Article Received: 18 October 2020, Revised: 3 November 2020, Accepted: 24 December 2020

\section{Introduction}

The issue of character becomes a very urgent problem in the development of the Nation in this country. Amid the euphoria of reform, the phenomenon of anorexic behavior, vandalism, vigilante attitude, negative global ethics transformation, as well as a personal relationship that has no heed to the moral values, is a very concern in the world of education in Indonesia. Adolescent delinquency, which often adorned news columns in the mass media, such as school skip, International student fights, theft, and extortion, as well as drug abuse, is a form of character education failure in the country. With this kind of phenomenon, the education of manipulation is a commitment to what steps the educator should take to direct the young generation to the understanding and internalization of values and virtues that will form them into good human beings. Ironically, the attention given by the world of National education to ethical education is still lacking, it can even say the handling of ethical education still abandoned due to educational orientation is more inclined to the dimension of Knowledge ${ }^{1}$.

Character building through an education unit conducted from early childhood education to higher education. The application of character education in the school environment must be applied to overcome the phenomenon of anarchism, control of wills, inter-student fights, distribution, and drug users, environmental crisis, moral crisis, and other social trends of pathology. Character education is very urgencies and urgent to do, thus encouraging several developed countries, such as the United States, Japan, and China applying character education models since elementary school to college ${ }^{2}$. to Solve this problem requires an evaluation model. Character

\footnotetext{
1 Suyanto, Suyanto. "Refleksi dan reformasi pendidikan di Indonesia memasuki milenium ketiga”, Yogyakarta: Adicita Karya Nusa, 2000.

${ }^{2}$ Wibowo, Agus. "Pendidikan karakter", Yogyakarta:

Pustaka Pelajar, 2012
} 
education evaluation models are indispensable to uncover obstacles in character education as well as to improve the quality of character education. According to Mardapi $(2000)^{3}$, evaluation in education reviewed from its target can differentiate into the macro and micro evaluation. The macro evaluation of the target is the general education program, which is a planned program to improve the education field. Meanwhile, micro evaluation often used at the class level. Thus, the target of micro evaluation is a learning program in the classroom. That which is responsible is the teacher for the school or lecturer for college. Teachers on each subject are responsible for arranging and implementing learning, and the principals are responsible for evaluating learning programs that have been compiled and implemented by teachers.

Based on the study and the analysis the problem is necessary to develop a model of the character Education evaluation Instrument that is more comprehensive and capable of providing accurate and precise information for teachers to improve students' character. Accurate and precise information terms include accurate and precise in terms of coverage, information content, and accurate and precise timing of delivery of information about a current or existing character education running. The general term has the meaning that the evaluation scope is not only on the output aspect but also covers the quality aspects of the character education program. Character education is not only limited to proficiency in academics, but also the personal character and social $\mathrm{K}$ is. Thus, it can explain that this research has the main objective to develop the instrument of Character education evaluation model with a sample of objects in MTs in the region of former Pekalongan residence, Central Java, Indonesia. With the development of a useful

\footnotetext{
${ }^{3}$ Mardapi, Djemari. "Pengembangan sistem penilaian berbasis kompetensi." Paper presented in Seminar Nasional Rekayasa Sistem Penilaian dalam Rangka Meningkatkan Kualitas Pendidikan, at Hotel Century-Saphir Yogyakarta. 2004.
}

construct is expected to improve the quality and quality of education, especially in the character representation of students in-class learning.

\section{Literature Review \\ Character Education}

Character education can interpret as value education, ethical education, moral education, or character education, aiming to develop the ability of students and students to make way decisions, nurture what is good, and realize that goodness in everyday life wholeheartedly ${ }^{4}$. Characters cannot develop in a short time. Character education has to go through a long series of processes and systems and requires accuracy. Based on the perspective that develops in the history of human thought, character education must be conducted based on children's developmental phases from early childhood to adulthood ${ }^{5}$.

Berkowitz and Bier argue that literary characters recommended for a variety of reasons. There is to do with the perception of "how the school should be" $^{16}$. It will ultimately relate to the results of student development and learning. Character education, however, is intended to promote the development of student character. Benninga and Wynne say the means of characters derived from the Greek word to mark or to Engrave, which has the meaning of ' marking, 'which can be interpreted as behavior characterized by a polite and engraved behavior in their hearts ${ }^{7}$. Meanwhile, Kemendiknas states that the character is a behavior based on values according to the norms of religion, culture, law/Constitution,

\footnotetext{
${ }^{4}$ Winataputra, Udin S. "Teori Belajar dan Pembelajaran", Jakarta: Universitas Terbuka, 2010.

${ }^{5}$ Majid, Abdul, \& Andayani, Dian."Pendidikan karakter dalam perspektif Islam”, Bandung: PT Remaja Rosdakarya, 2011.

6 Berkowitz, Marvin W., and Melinda C. Bier. "What works in character education: A research-driven guide for educators", Washington, DC: Character Education Partnership, 2005.

7 Benninga, Jacques S., and Edward A. Wynne. "Keeping in character: A time-tested solution", The Phi Delta Kappan 79.6 (1998): pp. 439-448
} 
customs, and aesthetics ${ }^{8}$. Character education is a planned effort to make students know, care, and internalize character values so that learners behave as good human being. It is as expressed by Berkowitz \& Bier that character education aims to teach students about fundamental human values that include honesty, goodness, kindness, courage, freedom, equality, and honor in the hope of making learners can be morally accountable ${ }^{9},{ }^{10}$.

\section{The Values of Character Education}

Minister of Education explain that environmental factors strongly determine the change in student behavior as a result of the character education process $^{11}$. Therefore, environmental formation and engineering that covers the physical and cultural environment of the school, school management, curriculum, educators, and teaching methods must carry out continuously. Character building through the engineering of environmental factors can do through several strategies, among others a) transparency, B) intervention, C) consistent habituation, and D) strengthening. All of these aspects will support the success of the learners' future. Therefore, to achieve success with a capital of intellectual intelligence alone is not enough. Islam has always positioned the formation of moral or child characters on the main pillars of educational purposes. To realize the formation of morality in the son of Al Ghazali, according to Rusn offers an educational concept

\footnotetext{
8 Indonesian Ministry of National Education. "Pendidikan karakter terintegrasi dalam pembelajaran di Sekolah Menengah Pertama", Jakarta: Direktorat PSMP Kemendiknas, 2010

9 Berkowitz, Marvin W., and Melinda C. Bier. "What works in character education: A research-driven guide for educators", Washington, DC: Character Education Partnership, 2005.

${ }^{10}$ Khan, S., Arshad, M. A., \& Khan, K. (2018). SelfDevelopment Through Soul Management: Context of Islamic Spiritual Intelligence. Research Journal of Commerce Education \& Management Sciences, 1(1).

11 Indonesian Ministry of National Education. "Pendidikan karakter terintegrasi dalam pembelajaran di Sekolah Menengah Pertama", Jakarta: Direktorat PSMP Kemendiknas, 2010. .
}

that aims to draw closer to $\operatorname{God}^{12}$. According to him, closer to God is the benchmark of human perfection and to go towards an approach to him. There is a bridge called Science.

Lickona stated that every school that wants to teach value education should believe that there are universal values to be taught in school and help learners understand, internalize, and act on those values $^{13}$. It means that character education is a deliberate effort by the school to embed those values. The definition means that character education is a deliberate effort to develop a good character based on ethical core values for individuals and society. this term consists of, moral knowing, moral feeling, and moral action. The three are very urgent to live a moral life and the forming factor of moral maturity. In other words, moral knowing, moral feeling, and moral action are inseparable but influence each other in various ways. Moral knowing can elicit moral feelings. Meanwhile, the moral feeling can also affect the moral of knowing. Moral Knowing and moral feeling influence each other's moral actions, especially when both are present together. A person's behavior usually affects the way it is like and how to feel like, for example, when someone condones and does good to someone else who previously makes his s furious, usually the person gets him that his thoughts and feelings toward the person are more favorable. A good character scheme starts from the knowledge of goodness (moral knowing), then raises commitment (intention) to goodness (moral feeling), and ultimately actually does good (moral action). In other words, the character refers to a series of knowledge (cognitive), attitudes (attitudes), and motivations, as well as behaviors (behaviors) and skills. According to Dewantara, people who have ethical intellect will always think, feel, and use

\footnotetext{
${ }^{12}$ Rusn, Abidin Ibnu, \& Kamdani, Kamdani. "Pemikiran AlGhazali tentang pendidikan”, Yogyakarta: Pustaka Pelajar, 1998

13 Lickona, Thomas. "Religion and character education", New York: The Delta Kappan, 1999.
} 
basic balanced rules ${ }^{14}$. Characters or ethics are constant, and every human being has it. Character or ethics is the result of the unity of thought, feelings, and will of strength.

\section{Character Education Objectives}

Character education can integrate into learning on any subject. Learning materials related to norms or values in each subject need to developed, exported, attributed to the context of daily life. Thus, learning character values not only on the cognitive level, but touching on internalization, and the real practice in the lives of everyday learners in the community ${ }^{15}$. Zuriah said that character education is the same as ethical education ${ }^{16}$. The purpose of ethics is to develop a character or habit of students by living the values of society's beliefs as the moral force of life through honesty, trustworthiness, and cooperation that emphasizes the realm of a constructive (feeling, attitude) without leaving the realm of cognitive and psychomotor realm. One can be said to be characteristic or character if it has successfully absorbed the values and beliefs that the community wants and used as a force in his life. The character of a nation, according to Zuchdi, has an essential and decisive role ${ }^{17}$. People who have a different character will have difficulty to be able to progress. It can say that the character is everything to the progress of a nation. The existence of strong characters, such as honesty, integrity, leadership, a strong desire to learn something, and courage to make a decision will lead to achievement and play a vital role.

\footnotetext{
${ }^{14}$ Dewantara, Ki Hajar. "Pemikiran, konsepsi, keteladanan, sikap merdeka II (Kebudayaan)", Yogyakarta: UST Press bekerja sama dengan Majelis Luhur Persatuan Tamansiswa, 2013

15 Fitri, Agus Zaenul. "Pendidikan karakter berbasis nilai dan etika di sekolah”, Yogyakarta: Ar-Ruzz Media, 2012. ${ }^{16}$ Zuriah, Nurul, and Fatna Yustianti. "Pendidikan moral \& budi pekerti dalam perspektif perubahan: menggagas platform pendidikan budi pekerti secara kontekstual dan futuristik", Bumi Aksara, 2008.

${ }^{17}$ Zuchdi, Darmiyati. "Pendidikan karakter dalam perspektif teori dan praktik", Yogyakarta: UNY Pres, 2011.
}

\section{Method}

This research includes development research (research and development), which is often abbreviated $\mathrm{R}$ \& $\mathrm{D}$. This research aims to: 1) produce a product in the form of a model of Character education evaluation instrument in Madrasah Tsanawiyah, 2) manual of the use of the model construction Instrument Character Education evaluation in Madrasah MTs. Model construction instrument education evaluation character developed in this study was named Model Construction Instrument Training evaluation of character in MTs based Tadzkiroh after this referred to the model KI-EPK.

In more detail, the $R \& D$ research procedure divided into ten stages. According to Borg and Gall, all the phases are as follows: (1) Research and information collecting (need analysis); (2) Planning (P); (3) Develop, preliminary form of product; (4), preliminary field testing; (5) Main Product revision; (6) playfield testing; (7) Operational Product revision; (8) Operational field testing; (9) Final Product revision; (10) dissemination and implementation ${ }^{18}$.

\section{Validity of instruments}

Besides designing the evaluation model, at this stage, I also compiled a research instrument. For the evaluation instrument to be valid, validate the content of the instrument. The compute the content-validity coefficient used formula Aiken. In this case, Aiken Formulating the Aiken's V formula with the formula $\mathrm{V}=\frac{\sum \mathrm{s}}{[\mathrm{n}(\mathrm{c}-1)]}$

This formula ${ }^{19}$ used to calculate the contentvalidity coefficient based on the assessment. The expert person against the questionnaire item from the extent to which the instrument represents the

18 Gall, Meredith Damien, Walter R. Borg, and Joyce P. Gall. "Educational research: An introduction", Longman Publishing, 1996.

${ }^{19}$ Aiken, Lewis R. "Three coefficients for analyzing the reliability and validity of ratings", Educational and psychological measurement, vol. 45, no. 1, 1985, pp. 131142 
measured construct. The assessment is done by giving the number 1 (for irrelevant item inquiries) up to 5 (for relevant item questions). In the preparation of this instrument, it involves some advice and opinions. It is experts in the form of FGD and the Delphi technique.

\section{Instrument reliability}

To measure the reliability of instruments used program SPSS for windows version 20 with statistical test formula Alpha Cronbach (a). According to Salkind, the amount of reliability can calculate by the Cronbach Alpha test ${ }^{20}$. According to Gliem \& Gliem (2003, p. 87), the reliability coefficient of Alpha Cronbach is ranging in size between 0 and 1 , but there is no lower limit for the coefficient ${ }^{21}$. The alpha coefficient can be said to have a good rally fine if the magnitude is approaching 1. According to George \& Mallery (2014, p. 240) The category of reliability value is if $>0.9=$ excellent; $>0.8=$ good; $>0.7=$ received, $>0.6=$ questionable; $>$ $0.5=$ poor; and $<0.5=$. Not acceptable.

\section{Model Revision}

This stage aims to determine the extent to which the evaluation model and the instruments and devices of the model can be applied to evaluate character education in the MTs level. This activity is performed if it meets the requirements as an instrument A good outcome, that is, analysis meets the validity index of Aiken's and the reliability of $>0.90$. Meanwhile, the validity of the construct is tested through an expanded trial and analyzed using the help of LISREL 8.5. The Data on the trial results expanded with the help of LISREL must meet the Goodness of Fit (GoF)

\footnotetext{
20 Salkind, Neil J. "Tests \& measurement for people who (think they) hate tests \& measurement (2nd ed.)", Sage Publications, 2017.

${ }^{21}$ Gliem, Joseph A., and Rosemary R. Gliem. "Calculating, interpreting, and reporting Cronbach's alpha reliability coefficient for Likert-type scales", Midwest Research-toPractice Conference in Adult, Continuing, and Community Education, 2003.
}

Criteria and Acceptable Fit Interpretation standards. The final stage is diffused through the study of the parties involved in the development, the user evaluation model, and the peer friend of the lecturer for the next made the final report.

\section{Figure 1. Model and Development Procedure}

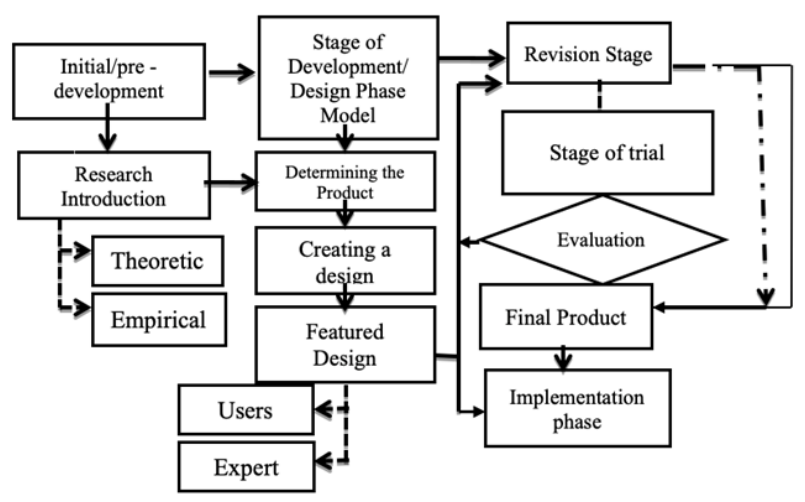

\section{Population and Research samples}

The sampling is taken in the study using the disproportionate stratified random sampling technique. This technique used due to the number of samples with a population of stratified but less proportional. This is due to the number of teachers smaller than the number of students so that the teacher is taken $50 \%$ as a sample of the number of existing populations. The sample for learners performed with the Proportional random sampling technique, which is to consider the proportions and samples. To know of the total sample, students used the Slovin formula with a degree of significance by $5 \%(0,05)$. The total number of population/respondents is a. MTSN 1 Pekalongan $=208$ students, B. MTSN 2 Pekalongan $=266$ students, c. MTSN 1 Pemalang = 379 students, and D. MTSN 2 Pemalang = 352 students. So, the number of respondents in this study is 1205 learners.

Meanwhile, the number of teachers was 16. Thus, the total population is 1221 persons by using the Slovin formula. With a population of 1221 and a significance of $5 \%$ (0.5) Hence, the calculation of sample withdrawal with the Slovin formula in this study is as follows. Based on the calculations, the number of samples in this study was 300 . 


\section{Data Collection Techniques}

In this study, questionnaires used to;1) capture data on the clarity of evaluation procedures and evaluation guidelines; 2) capture data and the effectiveness of evaluation models; 3) capture data on clarity and use of the Evaluation Guide; 4) capture data on the clarity of instructions on the implementation of evaluation, coverage of indicators, use of language, and the instrument stationery used to collect data. The respondent was the head of the Madrasah, teachers, and students; (2) The observation method is an instrument of observation sheet to measure the affective and psychomotor aspects of the student. This instrument used to capture data about the character's education process. The instrument then sought for its validity and reliability. Character Education Assessment section sought to validate its appearance and content. Here are the instrument grids developed

\section{Table 1. Questionnaire Instrument actualisation Value-character}

\begin{tabular}{ll}
\multicolumn{1}{c}{ Variable } & \multicolumn{1}{c}{ Aspects } \\
\hline Example & Responsibility \\
\cline { 2 - 2 } & Discipline \\
\cline { 2 - 2 } Referral & Simple look \\
\cline { 2 - 2 } Encouragement & Training and skill delivery \\
\cline { 2 - 2 } & Ralent and interest development \\
\hline Zakiyah & Religious \\
\cline { 2 - 2 } & Clean and healthy \\
\cline { 2 - 2 } & Honest \\
\hline \multirow{3}{*}{ Continuity } & School Culture and learning \\
& implementation \\
\cline { 2 - 2 } & Extracurricular \\
\hline \multirow{3}{*}{ Memory } & Smart \\
\cline { 2 - 2 } Reps & Smart oriented \\
\cline { 2 - 2 } & Science lover \\
\cline { 2 - 2 } & Rewarding learning Time \\
\cline { 2 - 2 } & $\begin{array}{l}\text { Appreciate the } \\
\text { achievements of others }\end{array}$ \\
&
\end{tabular}

Caring for the Classroom and school Environment

\begin{tabular}{ll}
\hline Organization & Democratic \\
\cline { 2 - 2 } & Nationalism \\
\cline { 2 - 2 } & Nationalism \\
\cline { 2 - 2 } & Mutual Cooperation \\
\cline { 2 - 2 } & Fair \\
\hline Heart & Empathy/Tolerance \\
\cline { 2 - 2 } & Respect for teachers \\
\cline { 2 - 2 } & Peace Love \\
\cline { 2 - 2 } & Qanâ'ah
\end{tabular}

Results

Results of preliminary study stage (Defining)

The main activities at this stage are preliminary research, theoretical studies, and relevant research studies. Preliminary research conducted to observe Islamic Schools at Pekalongan Residence and Pemalang in the year 2019. The purpose of this activity is to obtain preliminary information and data about the construction model of Character education evaluation instruments in MTs. At this stage, the observation was conducted at a glance to the learning process in the classroom and observing. The attitude of students both when following the learning process in class or when students are out of class.

\section{Result stage development (Designing)}

The second stage is the development/design stage of the KI-EPK model. This stage finish by the determination and creation of the KI-EPK model design validated by experts and practitioners. Prototype development model of the instrument construction Evaluation character Education in MTs, which has been dissemination with associates, then consulted to experts and practitioners to obtain validation. Members involved in this validation include experts in the field of Education Evaluation, instrument construction, and character education. They asked for an opinion about the model of the instrument construction evaluation character Education in MTs with the parts. Questionnaires filled in the 
form of statements using the Likert scale, i.e., always, often, sometimes, ever, and never with the ' criteria, always $=5$, often $=4$, sometimes $=3$, never $=2$, and not Never $=1$. Besides, the validator also gave space to provide opinions, proposals, and suggestions relating to the model and its parts. An expert assessment questionnaire to determine the validity of the content using five scales (Likert). The value of I-CVI should be 1.00 if there are five or fewer votes. Jik A There are six or more perillas I, the standard can be looser. In this case, Lynn recommends the I-CVI not lower than $0.78^{22}$. The Data presented in table 17, expert assessment Results, and educational practitioners showed that the CVI index value was 0.83 . Meanwhile, the total average score result of the instrument validation Assessment of the KIEPK Model of 4,33. The value of the Coefficient Validity Index (CVI) of the expert Assessment Results and the practitioner if it is converted with quantitative data scoring criteria to qualitative data with scale 5 in the category "Excellent." Therefore, the instrument on the KI-EPK model can use for Its continued research stage.

\section{Developing}

This stage consists of the test phase I (readability) and the Phase II trial (field feasibility and operation). Each of these stages will further describe in order to obtain a comprehensive picture. Trials in this research and development have several objectives. First, to know the suitability of KI-EPK model, the accuracy of KIEPK model, ease of use of KI-EPK model, and efficiency of the implementation of the KI-EPK model. Secondly, to find out if an instrument of the KI-EPK model can apply to evaluate character education in Madrasah MTS or not.

\section{Phase Limited Trials}

\footnotetext{
${ }^{22}$ Lynn, Marry R. "Determination and Quantification of Content Validity Index", Nursing Research, vol. 35, no. 6, 1986, pp. 382-386.
}

Stage I trials are the product development of KIEPK Model products. This Stage is the refinement of the model and its device after the instrument acquires evaluation and input from experts and practitioners. The next step is DRAF, the model KI-EPK and the devices that have been assessed by experts and practitioners are given to the user to assessed and given input. The user element involved is teacher MTs on the subjects of moral value, citizenship, Naturally Science, and Social Science in the area of the former resident of Pekalongan. The scale used to provide an assessment of the teacher response poll is $1-5$, with the criteria $5=$ very concur, $4=$ agree, 3 =Disagree, 2=Disagree, and $1=$ strongly disagree. This value is then converted from a quantitative to qualitative value, as presented in the following table 2 .

\section{Table 2. Quantitative Data conversion to qualitative Data}

\begin{tabular}{lll}
\multicolumn{1}{c}{ Formula } & \multicolumn{1}{c}{$\begin{array}{c}\text { Average score } \\
(\mathbf{X})\end{array}$} & \multicolumn{1}{c}{ Category } \\
\hline $\mathrm{X}>\bar{X}_{\mathrm{i}}+1.8 \mathrm{Sb}_{\mathrm{i}}$ & $\mathrm{X}>4.2$ & Ideal for use \\
\hline $\bar{X}_{\mathrm{I}}+0.6 \mathrm{sb} \mathrm{b}_{\mathrm{i}}<\mathrm{X} \leq \bar{X}_{\mathrm{i}}+1.8 \mathrm{sb}_{\mathrm{i}}$ & $3.4<\mathrm{X} \leq 4.2$ & Can be used with no revisions \\
\hline $\bar{X}_{\mathrm{I}}-0.6 \mathrm{sb}_{\mathrm{i}}<\mathrm{X} \leq+0.6 \mathrm{sb} \bar{X} i_{\mathrm{i}}$ & $2.6<\mathrm{X} \leq 3.4$ & Can be used with a slight revision \\
\hline $\bar{X}_{\mathrm{I}}-1.8 \mathrm{sb}_{\mathrm{i}}<\mathrm{X} \leq-0.6 \mathrm{sb} \bar{X} i_{\mathrm{i}}$ & $1.8<\mathrm{X} \leq 2.6$ & Can be used with many revisions \\
\hline $\mathrm{X} \leq \bar{X}_{\mathrm{i}}-1.8 \mathrm{Sb}_{\mathrm{i}}$ & $\mathrm{X} \leq 1.8$ & Not yet usable
\end{tabular}

The readability trials of KI-EPK models at stage I included 1) legibility of evaluation procedures, 2) readability of student and teacher character Assessment instruments, 3) Learning instrument readability, and 4) readability evaluation guidelines. The model test performed is the process of character education that occurs both inside and outside the classroom. The learning process includes a class climate, teacher, and student attitudes in the learning process. The legibility Assessment OF KI-EPK model by the teacher of moral value, citizenship, natural science, and social science at stage $\mathrm{I}$ is at a score of 4.7. When viewed from the scoring criteria, this KI-EPK model instrument is on the "very ideal use" criterion.

\section{Readability Trial Evaluation Procedure}


Assessment of the Readability Trial evaluation procedure Model EPK-MTs assessed by the user as many as five people, namely the teachers' Maple moral value, citizenship, natural science, social science, and the head of Madrasah. Readability aspects include a) clarity of the procedure/step evaluation; b) the use of the grammar rules. It is as follows: (1) The accuracy of use and writing of letters, (2) The accuracy of the wording, (3) The accuracy of punctuation, (4) The clarity of the sentence used, and (5) the use of understandable terms; c) Practicality aspects that include (1) practicality of the procedure (easy to follow) and (2) practicality of the way the presentation of the procedure (pure); D) Aspects of efficiency that include (1) efficiency in terms of time, (2) costs, and (3) energy. The legibility Test assessment showed that the value gained on the readability trial of the evaluation procedure was 4.7636. This means that the model of the character's educational evaluation instrument is on a "very ideal use" criterion.

\section{Instrument Readability Test}

At this stage, the assessment done by the user, namely teachers and the head of the Madrasah. Assessment focused on a) clarity of instrument instructions; b) K.the scope of the indicator of the affective sphere of the instrument; c) The use of the rules of writing that includes (1) accuracy of use and writing, (2) The accuracy of the wording, (3) The accuracy of punctuation, (4) The clarity of the sentence used, and (5) the use of understandable terms. The results of data collection and readability assessment indicate that the value gained on readability trials of the evaluation procedure is 4.87 . If viewed from the scoring criteria, the instrument of the KI-EPK model is in the criteria "very ideal to use."

\section{Test Model KI-EPK}

Teacher scoring instruments used to collect information about input components. The phase I trial held on 3 - 19 January 201 9, also known as a preliminary trial or preliminary field testing. The test is done by distributing a character education evaluation instrument that included input components and processes to 64 students at MTSN 1 Pekalongan in 2 classes. The class chosen was class VIII on the subject of the subjects of moral value and citizenship. The limited trial instrument aims to obtain information about the validity of a constructed instrument. The construct tested using a quantitative approach with the Confirmatory Factor Analysis (CFA) method using the help of the Lisrel 8.50 program for Windows. Results of the trial to show the construct has fiT created in 9 main variables i.e., 1) example, 2) Referrals, 3) Encouragement, 4) Zakiyah, 5) Continuity, 6) Memory, 7) Reps, 8) Organizations, and 9) hearts. Figure 7 The following is the initial construct constructed through the theory and validation of the instrument contents "Model EPK-MTs."

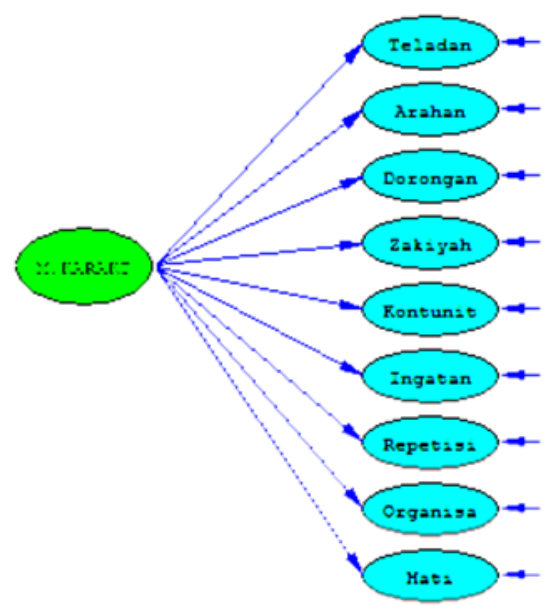

Picture 2. Conceptual Model KI-EPK Models

Next is analyzing the grains using SPSS to see the reliability of the instruments developed. The Parameter used to determine reliability is to look at the Cronbach Alpha value on each output table obtained, provided that if an Alpha index or the charge of the invoice is greater than or equal to $0.7(\alpha \geq 0.7)$, then the instrument includes reliability ( Khalek, 2016). Results of Alpha coefficients on limited-scale trials showed a value of $0.847(\geq 0.7)$. Its means built instruments are 
qualified for high reliability. The reliability value of the instrument presented in table 24 .

Table 24. Instrument Reliability Output of character Education Model

\section{Reliability Statistics}

Cronbach's Alpha

Cronbach's Based on Standardized

Alpha Items

\begin{tabular}{r|r} 
& N of Items \\
\hline .846 & 28
\end{tabular}

The next step is to perform the CFA analysis to see the magnitude of the loading factor in each component and the instrument developed. The estimated results indicated that the instrument "Model Construction Instrument evaluation character" for the Student Assessment Instrument (questionnaire) had a useful reliability index, as the $>0.7$ of the Alpha coefficient was 0.847 . The same is the case with the whole instrument "Model of Evaluation of the character indication instrument," which amounted to 28 items, has a value of loading factor $>0.3$ as much as 24 grains, stretched 4 grains have a loading factor under 0.3 , so it should be discarded. Table 3 explain the details of valid and invalid instruments.

Table 3. Results Loading Factor WITH CFA

\begin{tabular}{cll} 
No & Category & \multicolumn{1}{c}{ Grain } \\
\hline 1 & Valid & $1,2,3,4,5,6.7,8,9,11,12,13$, \\
& & $14,15,16,17,19,21,22,23,24$, \\
& & $25,26,27$ \\
\hline 2 & Invalid & $10,18,20,28$
\end{tabular}

Preliminary analysis results show that out of 28 items, there are 4 grains (Z2, R1, R3, and H4) does not meet the requirements of the loading factor, so it is issued and subsequent reanalysis. After reanalysis, 24 item meets the requirements of loading factor. They finish modifications obtained model fit with Parsimony type fit. Figure $8 \mathrm{~B}$ This IS the result of the CFA analysis and the recapitulation of the loading factor on the entire instrument questionnaire.

Fig. 3. Path of the payload Value Chart factor instrument

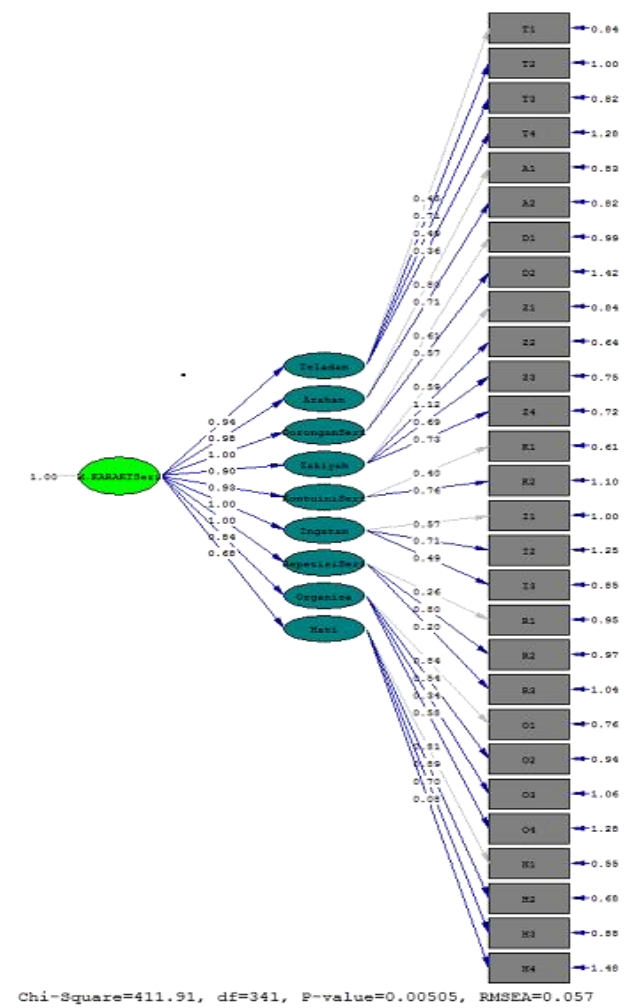


Figure 3. The charted path explains that the value of Chi-Square $=411.91$ with DF of 341 and Rmsea 0.057 (<0.08). To view model matches with empirical data or a fit model is described in some model match criteria. The model is said to be suitable if (Chi-Square) has significance (p), the value of GFI is $0,94(>0.90)$, and Rmsea is 0.057 (<0.08). Dimensions (level of significance $5 \%$ with a critical price $\mathrm{t}=1.98$. The structural equation diagram path above can explain the covariant relationship between variables with factors and indicators. After the test was conducted the factor in the CFA obtained ChiSquare 411.91 with $\mathrm{df}=341$, with $\mathrm{GFI}=0,68$ AGFI $=0,62$ and Rmsea $=0.057<0.08$. Then it can be concluded that the model made is fit with empirical data. The intercomponent diagram of the five components shows a high Lamda $(\gamma)$ value of $>0.3$. Hasil recapitulation of the loading factor structural model present in the following table 4.

Table 4. Results recapitulation of Loading FacTor structural Model

\begin{tabular}{clcl} 
No & Components & Loading FacTor & Decision \\
\hline 1 & Example & 0.94 & Excellent \\
\hline 2 & Referral & 0.98 & Excellent \\
\hline 3 & Encouragement & 1.00 & Excellent \\
\hline 4 & Zakiyah & 0.90 & Excellent \\
\hline 5 & Continuity & 0.93 & Excellent \\
\hline 6 & Memory & 1.00 & Excellent \\
\hline 7 & Reps & 1.00 & Excellent \\
\hline 8 & Organization & 0.84 & Good \\
\hline 9 & Heart & 0.68 & Medium
\end{tabular}

\section{Product test results}

Based on the test results of stage I, further completion of the draft in phase II. This trial is an important test/staple. At this stage, two instruments are tested, namely the teacher character assessment instrument in the form of questionnaires and observations and students ' character assessment instruments in the form of questionnaires. Step II conducted a large-scale trial with several respondents, 292 students, and eight teachers on 4 MTs in the area of three Residence in Central Java. Details of samples of schools taken, such as 2 Madrasah of Pekalongan Residence, and two Madrasah in Pemalang Residence.

\section{Unidimensional Instruments}

The unidimensional test conducted with factor analysis using SPSS 25 program. Before conducting the factor analysis, conducted feasibility testing analysis using the KMO-MSA test and Barlett's test on each instrument. According to Rovniak, Anderson, Winett, and Stephens, The terms of analytical factors are Kaiser-Meyer Olkin (KMO) - MSA > 0.5 and significant Barlet test for unidimensional, meaning each test item only measures one ability. To test the unidimesi with factor analysis. The results of the analyses of KMO and Barlett, s are less than 0.05. The KMO-MSA test uses to view sufficiency samples, which the test of Barlett's for the normality of the data used. The trial results can explain in table 5 below.

Table 5. KMO value and Barlett'e teacher rating instrument

KMO and Bartlett's Test ${ }^{\mathrm{a}}$

\begin{tabular}{lrr}
\hline Kaiser-Meyer-Olkin Measure of Sampling Adequacy. & .790 \\
\hline Bartlett's Test of Sphericity & Approx. Chi-Square & $1,565,062$
\end{tabular}




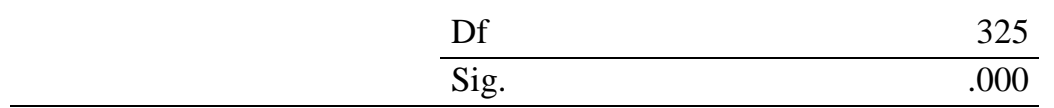

A. Based on correlations

On the explanation of table 5 , the results of the empirical analysis with the value of KMO-MSA are 0.79 or over 0.5 , and the test sig Barlett. $\mathrm{S}$ is 0.000 . Thus, it can conclude that SMUA results of analysis have been significant. It means, the insrumen are worth to do factor analysis. To obtain items that measure the same dimensions carried out the extraction process, resulting in several factors. The IAP Set factor has an eigenvalue, and the factor that has an Eigenvalue above 1.00 is retained (Santoso, 2007:60) . Next, if the first-factor Eigenvalue has a value of up to several times the value of Eigen, the second factor, and so on equal, then it is said that the unidimensional requirement met. The following table 6 displays cumulative variant totals.

Table 6. Total variant Kumulatif

\begin{tabular}{lccccccc} 
& \multicolumn{3}{c}{ Initial Eigenvalues } & \multicolumn{2}{c}{ Rotation Sums of Squared Loadings } \\
\cline { 2 - 8 } $\begin{array}{l}\text { Compo } \\
\text { nent }\end{array}$ & \multicolumn{3}{c}{$\begin{array}{c}\text { \% of } \\
\text { Total }\end{array}$} & $\begin{array}{c}\text { Cumulativ } \\
\text { Variance }\end{array}$ & $\begin{array}{c}\text { Total } \\
\text { e of }\end{array}$ & & $\begin{array}{c}\text { Cumulative } \\
\text { Variance }\end{array}$ \\
\hline 1 & 6.707 & 16.831 & 16.831 & 16.831 & 5.350 & 13.425 & 13.425 \\
\hline 2 & 3.120 & 7.828 & 7.828 & 24.659 & 2.361 & 5.924 & 19.349 \\
\hline 3 & 2.395 & 6.009 & 6.009 & 30.667 & 2.698 & 6.771 & 26.119 \\
\hline 4 & 1.936 & 4.857 & 4.857 & 35.524 & 2.335 & 5.859 & 31.979 \\
\hline 5 & 1.897 & 4.760 & 4.760 & 40.285 & 2.373 & 5.954 & 37.932 \\
\hline 6 & 1.816 & 4.556 & 4.556 & 44.841 & 2.233 & 5.603 & 43.535 \\
\hline 7 & 1.743 & 4.373 & 4.373 & 49.214 & 1.833 & 4.600 & 48.135 \\
\hline 8 & 1.615 & 4.052 & 4.052 & 53.266 & 2.045 & 5.131 & 53.266
\end{tabular}

Once known total variance in table 6 by $53.27 \%$ in the first component that interpreted, it measures one aspect with the dominant Eigenvalue, which is 13.43. It means, the instrument developed only measures one dimension of capability. His results can see on the Scree-Plot, an exploratory factor analysis that can describe in figure 13 below.

Fig. 4. Scree plot unidimensional test instrument assessment teacher

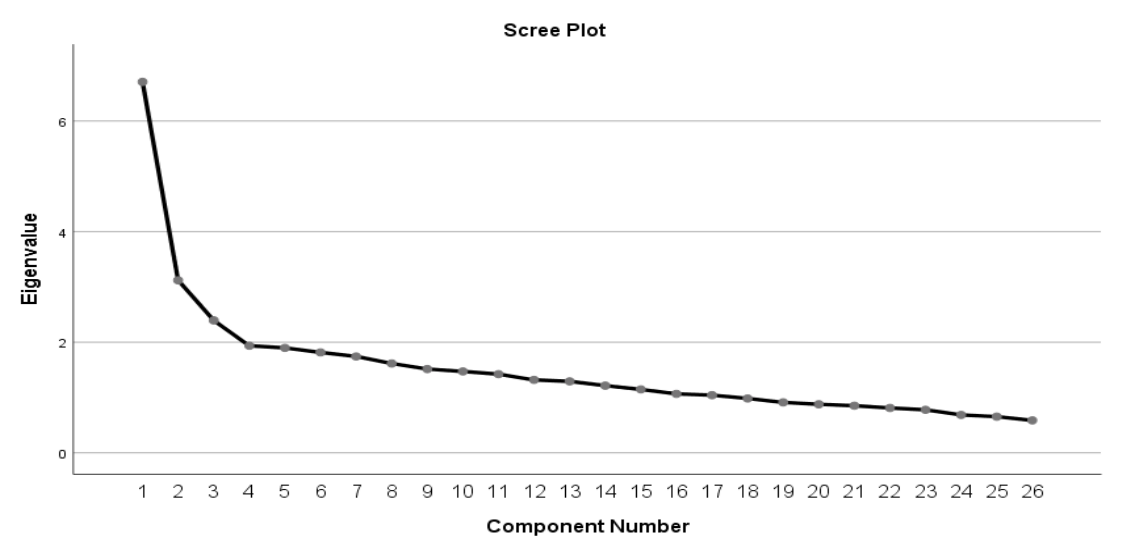

Figure 4 shows that the distance from component 1 to component 2 is far or multiple times the distance between other components. The steep
Scree-plot indicates the presence of dominant components. It means, religious instruments only measure one factor or one dimension. In subtests 
questionnaire instruments There are several things to be measured, namely the ability of teachers to master and guide the child in learning in the classroom.

\section{Model Match Test}

Through the technique, CFA can know whether any indicators are estimated to be valid measuring the dimensions of the concept tested, that is, by looking at the value Factor of loading. The following shows the results of the evaluation of the component Instrument model, accompanied by the estimation of reliability and validity. The wide-scale testing instrument involved 300 respondents in 4 MTs of State in the area of Pekalongan Residence. In the broad-scale product test, there are 26 items of the fit (with the loading factor > 0.5). Detail of the CFA Analysis Results presented in the following Figure 5 .

\section{Fig. 5. CFA Test Results Broad scale}

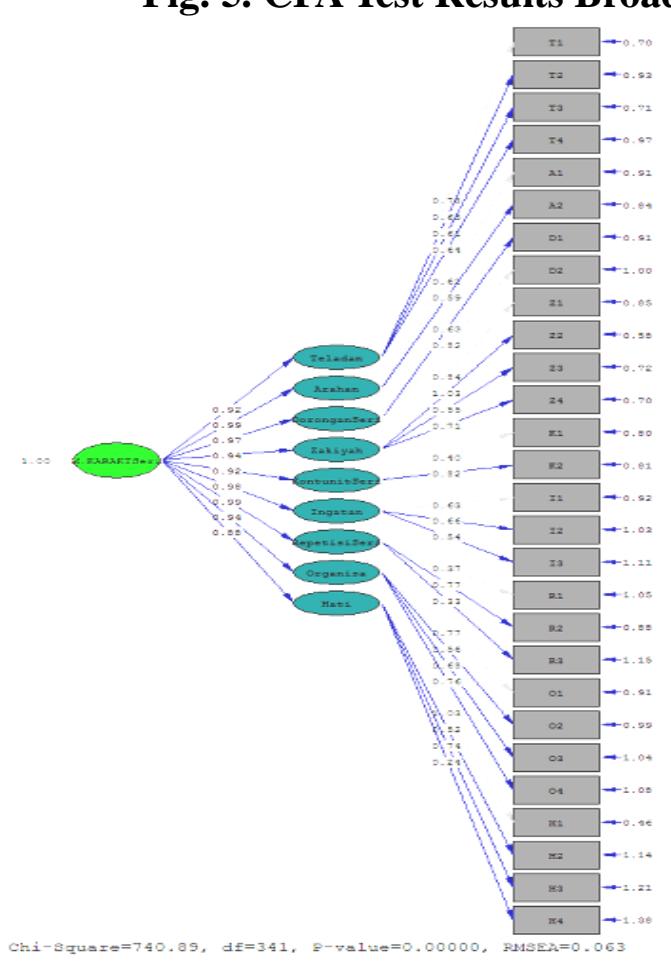

From figure 5 can be seen that the results of the wide-scale trial show that 24 items tested already have a value of loading factor more than 0.5 to the item that fits the model numbering 26 grains or including fit with models. The Model match test uses the parsimony fit Technique on limited trials with criteria; (a) The PNFI is 0.69 (0.6 S/d 0.9); (b) PGFI is $0.70(0.6-0.9)$; (c) AIC (812 < 978.88); (d) CAIC (1284.63 < 2721.74). So, it can conclude that with the parsimony fit technique, the model fit test. If compared to the broad-scale test results is (a) the PNFI is $0.80(0.6 \mathrm{~S} / \mathrm{d} 0.9)$; (b) PGFI is 0.77 (0.6-0.9); (c) AIC (541.91 < 982.47); (d) CAIC (747.24< 1070.92). So it can be concluded that the matching model fits with parsimony fit. Table 7 This join displays the recapitulation of the model match test using the normed parsimony Fit (PNFI) method.

\section{Table 7. Recapitulation of Model matches}

\begin{tabular}{|c|c|c|c|c|c|c|}
\hline No. & & & & Category & $\begin{array}{l}\text { Limited } \\
\text { trial }\end{array}$ & $\begin{array}{l}\text { Wide - scale } \\
\text { trials }\end{array}$ \\
\hline 1 & $\begin{array}{l}\text { Parsimonious } \\
(\mathrm{PNFI})\end{array}$ & Normed & Fit & $\begin{array}{l}(0.6 \mathrm{~S} / \mathrm{d} 0.9) \text {; The bigger } \\
\text { the better }\end{array}$ & 0.69 & 0.80 \\
\hline
\end{tabular}




\begin{tabular}{|c|c|c|c|c|}
\hline 2 & $\begin{array}{l}\text { Parsimonious Googness of Fit } \\
\text { Index (PGFI) }\end{array}$ & $\begin{array}{l}\text { ( } 0.6 \mathrm{~S} / \mathrm{d} 0.9) \text {; The bigger } \\
\text { the better }\end{array}$ & 0.70 & 0.77 \\
\hline 3 & 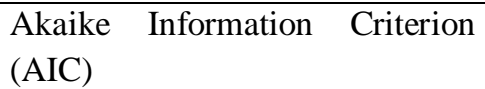 & Positive and smaller & 812 & 541.91 \\
\hline 4 & $\begin{array}{l}\text { Consistent Akaike Information } \\
\text { Criterion (CAIC) }\end{array}$ & Positive and smaller & 1284.63 & 747.24 \\
\hline
\end{tabular}

Table 7 indicates that there is an increase in the quality of the model matches from the limited trial stage with a broad-scale test stage of s-to-be inferred after the number of respondents has reproduced, the result will be increasingly fit with the model.

\section{Reliability Between Rater}

An observation instrument (rating) is a scoring procedure based on the subjective judgment of certain aspects and attributes carried out through direct or indirect systematic observation ${ }^{23}$. To reduce the subjectivity of scoring on the rating is done by more than one person rating (rater). The rating is done by several different raters and independent of each other against the same subject group. Although there is still a possibility of errors, but rather minimize the error of variant than by a re-rating procedure by a rater only. The Ratings made by many people will be more emphasis on the consistency of the inter-rater reliability. $\mathrm{Ebel}^{24}$ in Azwar ${ }^{25}$, giving its formula to estimate the reliability of the rating results carried out by as many as $\mathrm{K}$ raters against as many as $\mathrm{N}$ persons of the subject. Average reliability rating of both raters is $0,807(0,65)$. Thus, it can conclude that the average reliability index is consistent. The Data shows that the average yield on the reliability of a rater is 0,67 . Thus it can be concluded that the consistency of a rater includes good

\footnotetext{
${ }^{23}$ Azwar, Saifuddin. "Reliabilitas dan validitas (edisi ke 3)", Yogyakarta: Pustaka Pelajar, 1997.

${ }^{24}$ Ebel Robert L. "Essential of Educational Measurement, third edition", New Jersey: Prentice Hall. Inc, 1986.

${ }^{25}$ Azwar, Saifuddin. "Reliabilitas dan validitas (edisi ke 3)", Yogyakarta: Pustaka Pelajar, 1997.
}

\section{Character education evaluation results}

Input evaluation performed on several aspects of the assessment done by the data triangulation process and the addition of secondary data. The characters education present in the teacher is judged by the students. Students' assessment is done during learning, which is when teachers are out of class, and when teachers are in the classroom. Data retrieval in the form of questionnaires that have been tested both on a limited and broad basis. $H$ the descriptive character level of the teacher at the time of learning lasts an average of "good enough" on the nine aspects of character values. From the above data can then be spelled out into a chart or graph of a p-level bar diagram of the character to the teacher at MTs. Here is the result of a descriptive analysis.

\section{Figure 6. Master Character Level bar chart}

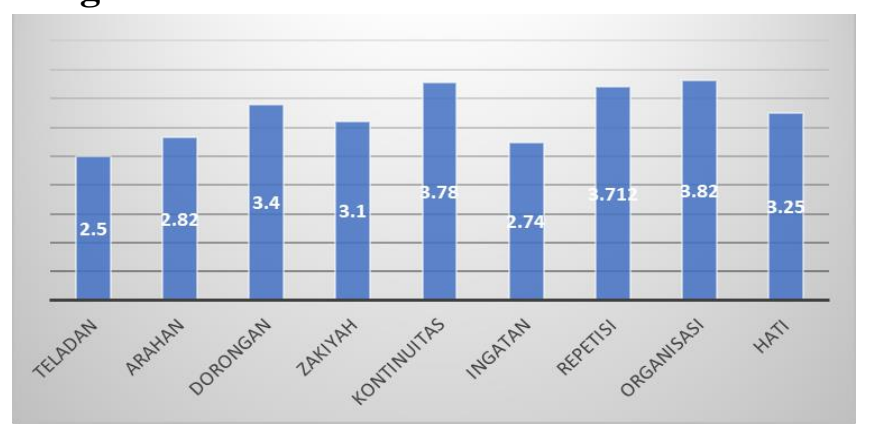

\section{Character levels in students}

Teachers judge the level of education of the character. The teacher's judgment was done while learning is when the teacher is out of class, and when the teacher is in the classroom. Data retrieval in the form of questionnaires that have been tested both on a limited and broad basis. The descriptive character level of the teacher at the 
time of learning lasts an average of "good enough" on the nine aspects of character values. From the above data can then be spelled out into a chart or graph of a p-level bar diagram of the character to the teacher at MTs. Figure 6 shows that this is the result of a descriptive analysis

\section{Fig. 7. Master Character Level bar chart}

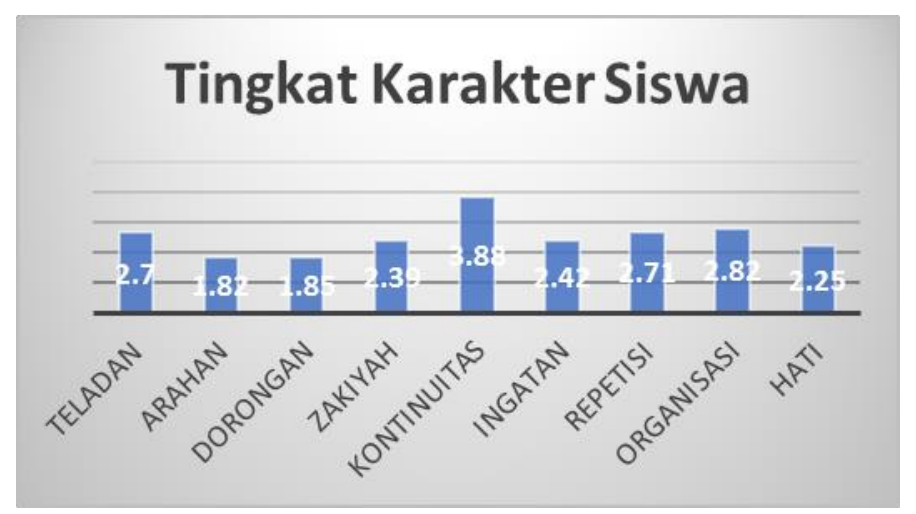

\section{Process Evaluation}

The evaluation process conducted to observe. How the implementation of character education in each school or district. The evaluation of character education is associated with three sub-variables, namely the preliminary, core, and concluding activities of the learning process. The observed respondents were teachers of subjects in the eyes of Islamic Studies, Citizenship, Natural Science, and Social Science. In this case, researchers use an observation sheet consisting of 51 grains. Here is the result of descriptive how the learning process that implements the of the character in MTs. Process evaluation data in the form of learning observation results in a class conducted by the rater or observer. The observation of the learning process results includes a. Learning outcomes at the introductory stage, B. Results of the learning process, and C. teacher performance results.

\section{Teacher Performance Results}

Teachers implement character education in the classroom. To obtain the results of teacher performance in the implementation of character education, observation during the learning process takes place. Based on the results of observing the teacher's performance showed a percentage of the amount of learning performance by the teacher was $76,4 \%$. Thus, the performance of teachers in the learning process is a very good category (>75). Figure $19 \mathrm{Be}$ participated is the average score from teacher performance taken from an observation data of 8 teachers in 4 schools.

\section{Figure 8. Teacher Performance Observation Results}

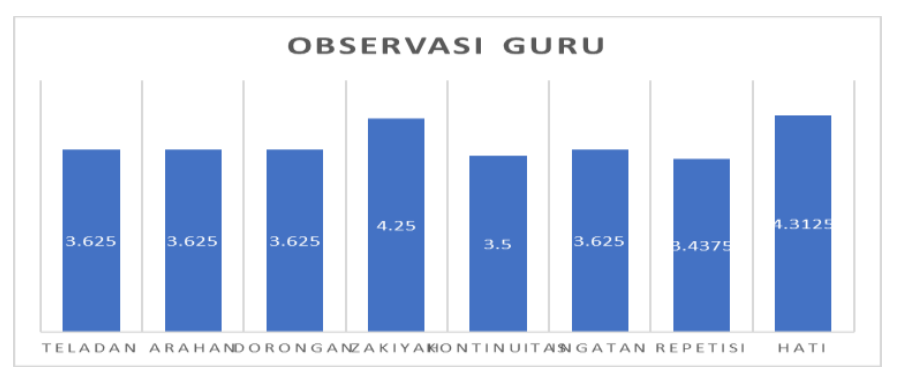


The teacher's observation shows that the most prominent aspect is the heart indicator consisting of: (1) empathy, (2) Courtesy, (3) Peaceful Love, and (4) Qanâ'ah. The "Heart" indicator has a score of 4.312 with the "excellent" category so that the application of heart value in the learning process is maximal. The lowest performance indicator is on "reps" consisting of: (1) Rebuke the students, (2) caring for the Environment, (3) Appreciating the time, and (4) appreciate the work of students who are in the category of "Medium."

\section{The effectiveness of Model KI-EPK}

Twenty-one people assessed the effectiveness of the product/model, each consisting of 4 head of Madrasah and 16 teachers in 4 Madrasah, the teacher of study in moral value, citizenship, natural science, and social science. The assessment focuses on aspect 1) clarity of the procedure; 2) The use of the Ordinance rules which include; (a) the accuracy of use and writing of letters, (b) the accuracy of the word writing, (c) the accuracy of the usage of punctuation, (d) The clarity of the sentence used (e) The use of terms that are easy to understand; 3) component comprehensive models and instrument indicators, 4) practicality of guidelines and instruments, and 5) efficiency of time, cost, and energy. This value is converted from a quantitative value to qualitative that the outcome of the effectiveness of the Construction Model of a Character education evaluation instrument in MTs is at a score of 4.31. When viewed from the scoring criteria, this KIEPK model instrument is on the "very ideal use" criterion. Thus, it can be concluded that the KIEPK model is advantageous if used to assess the students.

\section{Product revision}

Product revision of the construction Model of Education evaluation Instrument in MTs after obtaining expert assessment or validation and related to this field, there are many changes compared to the proposed initial product. In more detail, the revision of this product is about three things, namely evaluation Guide, Data Collector instrument, and scoring guideline format. The enhancement of "Model construction Instrument Character Education evaluation" concerns several things, such as the following. In the early preparation of the model of the instrument, using four variables, among others, a) thought; b) Exercise; c) Sports; d) the result revision is replaced with 9 Aspects of character compiled in a word Tadzkiroh. A spec of these characters formulated into nine main variables, among others A) exemplary; b) referrals, c) encouragement, D) zakiyah, E) continuity, F) memory, g) repetition, H) organizations, and, I) Hearts. Reduce the number of many grains, because charging by the respondent will not be objective and practical. The instrument is a reduction among others as follows: (1) Teacher character assessment instrument by students, which initially amounted to 171 changed to 28 grains, and after the validation of the construction changed to 24 grains; (2) The teacher's character assessment instrument, which initially amounted to 171 , changed to 23 rounds; (3) Learning observation instrument by Supervisor/principal from 89 to 21 item.

\section{Final Product Review}

Character education evaluation models and their devices have tested for implementation. The test results showed that the implementation of this model is quite practical and objective. Quantitative test result at medium-scale using SPSS program (main field testing) using Lisrel 8.50 program indicates that the model evaluation instrument has all fulfilled the reliability coefficient, the instruments are valid, and the models meet the FI requirements $\mathrm{T}$ model. Based on quantitative and qualitative analysis results as described in the previous section, it is understandable that the evaluation of character education with these Borg \& Gall models can categorize as a good model. That because it has 
properties; (1) valid, (2) reliable, (3) objective, (4) practical, (5) efficient, and (6) can provide precise information to the head of Madrasah, teachers, supervisors of Islamic education, both in terms of content, scope, format and delivery time and benefit optimally for the implementation of character education.

Another advantage of the findings of model construction Instrument evaluation of educationbased Tadzkiroh can explain in among others. Its following : (1) can guide/map evaluation and expected outcomes; (2) can help clearly about what activity is being implemented, what hope will be achieved, and how to measure the success of learning; (3) can serve as an evaluation monitoring tool and help identify key questions, for example: whether the underlying component evaluation model has been implemented, how the achievement of output components and outcomes has been achieved.

\section{Model KI-EPK}

This stage is the implementation stage of the model in Madrasah MTS after passing the revision and trial phases I and II. At this stage, the KI-EPK model can implement to evaluate the character education in Madrasah Tsanawiyah. The construction model of a Character education evaluation instrument based on TADZKIROH in Madrasah Tsanawiyah is called KI-EPK model. This model evaluates the character education in MTs, which is to evaluate the input and quality (process) of character education. With the implementation of this model KI-EPK, can be measured whether the character education in the MTS attends well or not good.

\section{Conclusion and Discussion}

The construct Model of this instrument can be used to evaluate the character education of students of class VIII MTs with some components of excess and deficiency. First, advantages the constructed model of this instrument, among others (a) can provide clear guidance on the evaluation of character education at Madrasah, (b) serves as a character level report students and teachers so that it can be done analysis needs in the determination of character formation program in the Madrasah. Secondly, the weakness of this evaluation model; among others (a) less effective if the time available to complete research is limited, (b) to uncover and record the learning process and progress of students achieved from learning outcomes takes a long observation time, (c) Instruments evaluation model involves a lot of students as respondences so that if many students are given instruments, students will feel bored. Meanwhile, the responses of teachers, students and head of Madrasah in assessing the effectivity of the model of the instrument of the character Education evaluation is very good with expectations to score $96 \%$;

Research on this character uses to build an evaluation model for character education that can provide information for school leaders and teachers in the high school level. This research has similarities with the research studies, namely in the discussion of character education. However, the above research has a point of difference with the research that is the study that the research examines the model of character Education evaluation in high school. In contrast, the research studies discussing the model of character education evaluation instrument.

Research Endicott ${ }^{26}$ et al. (2008, pp. 3 - 10) about "Teacher self-Efficacy For moral education: Measuring teacher Self-Efficacy For moral education" exposes Self-Efficacy instructional as a useful one key of teacher and student outcomes in Moral education. The results showed applied teachers for following the standard scale development procedure. Seventeen items generated and inserted into the analysis factor generate a scale of 13 items. The Item gives to 76

\footnotetext{
${ }^{26}$ Endicott, Leilani, Tonia Bock, and Darcia Narvaez. "Moral reasoning, intercultural development, and multicultural experiences: Relations and cognitive underpinnings", International Journal of Intercultural Relations, vol. 27, no. 4, 2003, 403-419 [https://doi.org/10.1016/S0147-1767(03)00030-0]
} 
secondary school teachers. TEME shows good validity, correlated with higher values in attitudes that are usually held by triumphant teacher success to help students learn, and efficacy to promote positive relationships as well as to measure the success of the related character education. TEME also correlates to teachers per school media. TEME is a useful measure to be used in evaluating the effects of preservice and inservice programs that emphasize moral character in students. Result It exposes the instruction of self-efficacy as an effective one key of teacher and student outcomes in moral education. This research is different from research that current studies on the specification side of school level study. The results of the study did not associate the specific moral education in MTs so that the research practice was different from the research studies. Therefore, it can say that the study related to the development of the model of the instrument of educational evaluation of the Karakater has a different position than the above research.

Holtzapple $^{27}$ et.al $(2011$, pp. 57 - 60) explained the program of character education that supports the development of positive characters in children and adults. A comprehensive program of education or character prevention that applies in schools is a program that affects the school as a community. The purpose of this report is to demonstrate how the prestigious archive data combined with a stratification approach for analysis can use to reduce the number of schools needed in a study involving a thorough and thorough intervention in school. Obtaining necessary information from the school's archival data for stratification before starting the study helps researchers, school districts, and other stakeholders in selecting a place of study (before the plainness) that will provide the most excellent probability that changes in behavioral outcomes can measure if they occur. Hotzapple discusses

\footnotetext{
${ }^{27}$ Holtzapple, Carol K., et al. "Implementation of a schoolwide adolescent character education and prevention program: Evaluating the relationships between principal support, faculty implementation, and student outcomes", Journal of Character Education 9.1, 2011: p. 71.
}

character education program that supports the development of positive character in children and adults. In theory, this research enriches researchers in formulating character education theories. This research is different from studies before. The point of difference lies in school specifications. The research that is studied is specific to the MTslevel. Therefore, the research practice that is studied is different from Holtzapple research.

Rofiuddin's ${ }^{28}$ research, showing the existence of the deviant behavior of students, such as cheating, fogging, avoiding subjects, and disturbing friends both inside and outside the classroom. Relevant to the Amalia ${ }^{29}$ research indicates the presence of several negative behaviors of students in the Madrasah neighborhood, such as demeanor, disobeying ethics, norms, and madrasah codes of conduct, and likes to break down. Both studies demonstrate some attitudes of the students irregularities, among others not working on the task of the teacher, Fitting, late school, lying with the teacher, not wearing uniforms according to the schedule, not wearing the attributes of the school, do not wear kopyah (headgear), disrespectful with the teacher, wear jewelry, and leave the class without the teacher's permission and during lesson hours.

\section{Summary of Products}

Based on the research and development results presented in the previous chapter, there are several things related to the research. They can find summary of product as follows: (1) Model construct the character education evaluation instrument has been developed by the contents and the construct so that the FIT model is

\footnotetext{
${ }^{28}$ Rofiuddin, Rofiuddin. Hubungan antara prestasi belajar kognitif mata pelajaran akidah akhlak dan tingkat penyimpangan perilaku peserta didik di MTs NU 01 Banyuputih Batang tahun pelajaran 2012/2013. Bachelor Degree. Thesis. Institut Agama Islam Negeri Walisongo, 2013.

${ }^{29}$ Amalia, F. (2016). Peran guru PAI bagi pembentukan karakter siswa di Madrasah Tsanawiyah YMI Wonopringgo Kabupaten Pekalongan. Bachelor Degree. Thesis. Sekolah Tinggi Agama Islam Negeri Pekalongan
} 
obtained, judging by the following indicators: (a) Chi-Square, $\mathrm{p}>0.05$, the obtained value of $=0$, 789.9; (b) The Goodness of Fit Indices (GFI) must range between 0 and 1, the value obtained $=$ 0.83; (c) Root Mean Square Error of Approximation (RMSEA) $<0.05$, the value obtained $=0.071$. Expert judgment for face validity and content validity on the model has been good (0.73), while the validation of the construction with confirmatory factor analysis obtained results that all variables appear to have a factor payload value $(\lambda)>0.30$. The reliability estimation of model instruments uses the Cronbach Alpha formula and meets the minimum standard index requirements, which is above 0.7; (2) model construct instrument Evaluation of character Education that is conceptualized from the value of Tadzkiroh (exemplary, direction, encouragement, Zakiyah, continuity, memory, repetition, organization, and Heart) empirically been declared feasible in the implementation test by user so that this model is suitably applied in MTs because this model can provide comprehensive information; (3) The results showed that the Goodness of Fit (GoF) was in a wide-scale trial, meaning that the instrument developed meets the model's match test.

\section{References}

[1] Aiken, Lewis R., "Three coefficients for analyzing the reliability and validity of ratings", Educational and psychological measurement, vol. 45, no. 1, 1985, pp. 131-142

[https://doi.org/10.1177/001316448545101 2]

[2] Amalia, F.," Peran guru PAI bagi pembentukan karakter siswa di Madrasah Tsanawiyah YMI Wonopringgo Kabupaten Pekalongan”, Bachelor Degree. Thesis. Sekolah Tinggi Agama Islam Negeri Pekalongan. https://docplayer.info/46833892-Bab-iii- peran-guru-pai-bagi-pembentukankarakter-siswa-di-madrasah-tsanawiyahymi-wonopringgo-kabupatenpekalongan.html.

[3] Azwar, Saifuddin. "Reliabilitas dan validitas (edisi ke 3)", Yogyakarta: Pustaka Pelajar, 1997.

[4] Benninga, Jacques S., and Edward A. Wynne. "Keeping in character: A timetested solution", The Phi Delta Kappan 79.6 (1998): pp. 439-448.

[5] Berkowitz, Marvin W., and Melinda C. Bier. "What works in character education: A research-driven guide for educators", Washington, DC: Character Education Partnership, 2005.

[6] Gall, Meredith Damien, Walter R. Borg, and Joyce P. Gall. "Educational research: An introduction", Longman Publishing, 1996.

[7] Gliem, Joseph A., and Rosemary R. Gliem. "Calculating, interpreting, and reporting Cronbach's alpha reliability coefficient for Likert-type scales", Midwest Research-to-Practice Conference in Adult, Continuing, and Community Education, 2003.

[8] Dewantara, Ki Hajar. "Manusia menuju merdeka", Yogyakarta: Leutika, 2009.

[9] Dewantara, Ki Hajar. "Pemikiran, konsepsi, keteladanan, sikap merdeka II (Kebudayaan)", Yogyakarta: UST Press bekerja sama dengan Majelis Luhur Persatuan Tamansiswa, 2013.

[10] Ebel Robert L. "Essential of Educational Measurement, third edition", New Jersey: Prentice Hall. Inc, 1986.

[11] Endicott, Leilani, Tonia Bock, and Darcia Narvaez. "Moral reasoning, intercultural development, and multicultural experiences: Relations and cognitive underpinnings", International Journal of 
Intercultural Relations, vol. 27, no. 4, 2003, 403-419

[https://doi.org/10.1016/S0147-

1767(03)00030-0]

[12] Fitri, Agus Zaenul. "Pendidikan karakter berbasis nilai dan etika di sekolah", Yogyakarta: Ar-Ruzz Media, 2012.

[13] George, Darren, and Paul Mallery. "IBM SPSS statistics 23 step by step: A simple guide and reference", New York: Routledge, 2016.

[14] Holtzapple, Carol K., et al. "Implementation of a school-wide adolescent character education and prevention program: Evaluating the relationships between principal support, faculty implementation, and student outcomes", Journal of Character Education 9.1, 2011: p. 71.

[15] Indonesian Ministry of National Education. "Pendidikan karakter terintegrasi dalam pembelajaran di Sekolah Menengah Pertama”, Jakarta: Direktorat PSMP Kemendiknas, 2010.

[16] Abdel-Khalek, Ahmed M. "Introduction to The Psychology of Self Esteem", University of Alexandria, Egypt: Nova Science Publishers, Inc, 2017.

[17] Lickona, Thomas. "Religion and character education”, New York: The Delta Kappan, 1999.

[18] Lynn, Marry R. "Determination and Quantification of Content Validity Index", Nursing Research, vol. 35, no. 6, 1986, pp. 382-386

[https://doi.org/10.1097/00006199-

198611000-00017]

[19] Majid, Abdul, \& Andayani, Dian."Pendidikan karakter dalam perspektif Islam”, Bandung: PT Remaja Rosdakarya, 2011.
[20] Mardapi, Djemari. "Pengembangan sistem penilaian berbasis kompetensi." Paper presented in Seminar Nasional Rekayasa Sistem Penilaian dalam Rangka Meningkatkan Kualitas Pendidikan, at Hotel Century-Saphir Yogyakarta. 2004. Barnhart, R. K. (Ed.). (1988). Chambers dictionary of etymology. New York, NY: The H. W. Wilson Company

[21] Rofiuddin, Rofiuddin. Hubungan antara prestasi belajar kognitif mata pelajaran akidah akhlak dan tingkat penyimpangan perilaku peserta didik di MTs NU 01 Banyuputih Batang tahun pelajaran 2012/2013. Bachelor Degree. Thesis. Institut Agama Islam Negeri Walisongo, 2013. http://eprints.walisongo.ac.id/539/ accesed 6 January 2020

[22] Rovniak, Liza S., Anderson, Eileen S., Winett, Richard A., \& Stephens, Robert S. "Social cognitive determinants of physical activity in young adults: a prospective structural equation analysis", Annals of Behavioral Medicine, vol. 24, no. 2, 2002, pp.

$149-156$ [https://doi.org/10.1207/S15324796ABM2 402_12]

[23] Rusn, Abidin Ibnu, \& Kamdani, Kamdani. "Pemikiran Al-Ghazali tentang pendidikan”, Yogyakarta: Pustaka Pelajar, 1998.

[24] Salkind, Neil J. “Tests \& measurement for people who (think they) hate tests \& measurement (2nd ed.)", Sage Publications, 2017.

[25] Khan, S., Arshad, M. A., \& Khan, K. (2018). Self-Development Through Soul Management: Context of Islamic Spiritual Intelligence. Research Journal of Commerce Education \& Management Sciences, 1(1).

[26] Santoso, Singgih. "Structural equation modelling: Konsep dan aplikasi dengan 
AMOS”, Jakarta: PT. Elex Media

Komputindo, 2007: p. 99.

[27] Suyanto, Suyanto. "Refleksi dan reformasi pendidikan di Indonesia memasuki milenium ketiga", Yogyakarta: Adicita Karya Nusa, 2000.

[28] Wibowo, Agus. "Pendidikan karakter", Yogyakarta: Pustaka Pelajar, 2012.

[29] Winataputra, Udin S. "Teori Belajar dan Pembelajaran", Jakarta: Universitas Terbuka, 2010.

[30] Zuchdi, Darmiyati. "Pendidikan karakter dalam perspektif teori dan praktik", Yogyakarta: UNY Pres, 2011.

[31] Zuriah, Nurul, and Fatna Yustianti. "Pendidikan moral \& budi pekerti dalam perspektif perubahan: menggagas platform pendidikan budi pekerti secara kontekstual dan futuristik”, Bumi Aksara, 2008. 